DOI https://doi.org/10.30525/978-9934-588-92-1-46

\title{
ДО ПИТАННЯ УЧАСТІ ІНОЗЕМЦІВ У НАГЛЯДОВИХ РАДАХ ПІДПРИЄМСТВ ДЕРЖАВНОГО СЕКТОРУ ЕКОНОМІКИ
}

\author{
Черненко О. А. \\ кандидат юридичних наук, \\ стариий науковий співробітник \\ Науково-дослідного інституту приватного права і підприємництва \\ імені академіка Ф. Г. Бурчака \\ Національної академї правових наук Украӥни \\ м. Київ, Україна
}

Законом України «Про внесення змін до деяких законодавчих актів України щодо управління об'єктами державної та комунальної власності» від 02.06.2016p. було внесено суттєві зміни в управління суб'єктами державного та комунального секторів економіки шляхом включення до органів управління згаданих підприємств такого органу, як наглядова рада, яка в межах компетенції, визначеної статутом підприємства та законом, контролює і регулює діяльність керівника підприємства.

Доцільність створення наглядової ради як органу контролю, що покликаний захищати інтереси власників компанії, визнана у багатьох країнах світу. В корпоративних підприємствах компетенцію наглядової ради розглядають з поділом на три групи:

1) повноваження щодо контролю за роботою виконавчого органу (укладення від імені товариства контракту з керівником, затвердження умов договорів з головою (членами) правління та ін.);

2) повноваження щодо роботи з акціонерами (організація і контроль за виконанням рішень загальних зборів, узгодження порядку денного $\mathrm{i}$ попередній розгляд питань, включених до неї, вимога про скликання позачергових зборів тощо);

3) повноваження щодо вирішення фінансових питань діяльності товариства (визначення основних напрямів діяльності товариства і затвердження його планів, узгодження правочинів; вибір аудитора та ін.) [1].

Окремі питання формування та функціонування наглядових рад розглядались у працях таких вчених, як О. М. Вінник, Д. В. Задихайло, О. Р. Кібенко, І. В. Лукач, Д. І. Погрібний, І. В. Спасибо-Фатєєва та ін. 
У науковій літературі існують різні думки щодо формування наглядової ради в акціонерному товаристві:

1) виключно з числа акціонерів;

2) із членів від акціонерів і від найманих працівників;

3) не лише 3 акціонерів та їх представників, а й $з$ кваліфікованих спеціалістів: економістів, фінансистів, банкірів тощо;

4) $з$ незалежних осіб, які не представляють інтереси будь-кого 3 акціонерів.

На сьогодні у провадженні Конституційного суду перебуває конституційне подання 48 народних депутатів України щодо відповідності Конституції України (конституційності) окремих положень Господарського кодексу України, Закону України «Про управління об’єктами державної власності» від 21 вересня 2006 року № 185-V зі змінами, вимог до незалежного члена наглядової ради державного унітарного підприємства та господарського товариства, у статутному капіталі якого більше 50 відсотків акцій (часток) належать державі, затверджених постановою Кабінету Міністрів України від 10 березня 2017 року № 142, Порядку визначення та затвердження кандидатур представників держави, які призначаються до наглядових рад державних унітарних підприємств, i тих, які беруть участь у загальних зборах та обираються до наглядових рад господарських товариств, у статутному капіталі яких більше 50 відсотків акцій (часток) належать державі, затвердженого постановою Кабінету Міністрів № 143.

Тому постає питання щодо уможливлення призначення незалежними членами до наглядових рад державного унітарного підприємства та господарського товариства, у статутному капіталі яких більше 50 відсотків акцій (часток) належать державі, 3 числа осіб, які мають громадянство іноземних держав.

Норми Закону України «Про управління об'єктами державної власності» та Вимоги до незалежного члена наглядової ради державного унітарного підприємства та господарського товариства, у статутному капіталі якого більше 50 відсотків акцій (часток) належать державі, затверджені Постановою Кабінету Міністрів України від 10 березня 2017 р. № 142, не вимагають наявності у фізичної особи, що призначається (обирається) на посаду незалежного члена наглядової ради громадянства України. При конкурсному відборі мають перш за все враховуватись освіта, досвід роботи та професійні навички, тому незалежний член наглядової ради має відповідати таким вимогам:

- наявність повної цивільної дієздатності;

- наявність вищої освіти, професійних знань та навичок, досвіду роботи та інших характеристик, необхідних для належного здійснення 190 
повноважень члена наглядової ради, що відповідає видам діяльності державного унітарного підприємства та господарського товариства, у статутному капіталі якого більше 50 відсотків акцій (часток) належать державі;

- добропорядність, неупередженість та бездоганна ділова репутація;

- не посідати виборні посади та не бути посадовою особою органів державної влади та/або місцевого самоврядування;

- відсутність непогашеної судимості;

- відповідність іншим вимогам та володіння необхідними компетенціями, визначеними комісією 3 конкурсного відбору кандидатів на посаду незалежного члена наглядової ради державного унітарного підприємства та господарського товариства, у статутному капіталі якого більше 50 відсотків акцій (часток) належать державі, що не можуть відрізнятись від інших вимог та необхідних компетенцій, визначених для представників держави, що призначаються (обираються) до наглядової ради такого підприємства, господарського товариства.

Стаття 26 Конституції України, ч. 1 ст. 3 Закону України «Про правовий статус іноземців та осіб без громадянства» від 22 вересня 2011 року закріплюють принцип національного правового режиму для іноземців та осіб без громадянства, що перебувають в Україні на законних підставах.

Конституцією та законами України іноземцям та особам без громадянства гарантуються особисті (громадянські) права, що належать до загальновизнаного переліку природних прав: право на життя та його захист; право на повагу до гідності; право на шлюб i сімейні відносини; право на таємницю листування, телефонних розмов, телеграфної та іншої кореспонденції; право на невтручання в особисте і сімейне життя; право на свободу та особисту недоторканність; право на недоторканність житла; право на свободу пересування, вільний вибір місця проживання; право на свободу думки і слова, на вільне вираження своїх переконань тощо. Іноземці в Україні можуть володіти, користуватись і розпоряджатися своєю власністю, результатами своєї інтелектуальної, творчої діяльності, здійснювати підприємницьку діяльність тощо.

Відповідно до ст. 3 Закону України «Про правовий статус іноземців та осіб без громадянства» іноземці та особи без громадянства, які в'їхали в Україну на законних підставах, вважаються такими, які тимчасово перебувають на території України на законних підставах на період наданого візою дозволу на в'їзд або на період, встановлений законодавством чи міжнародним договором України. 
Враховуючи вищенаведене, можна зробити висновок, що на посади незалежних членів наглядової ради мають право нарівні з громадянами України приймати участь у конкурсі іноземні громадяни та особи без громадянства. Проте слід зазначити, що член наглядової ради державного унітарного підприємства, господарського товариства, у статутному капіталі якого більше 50 відсотків акцій (часток) належать державі, має право на оплату своїх послуг $y$ вигляді річної і додаткової винагород та на компенсацію витрат, пов'язаних з виконанням ним своїх функцій, на умовах, визначених у цивільно-правовому договорі, що затверджуються загальними зборами товариства, суб'єктом управління об'єктами державної власності, до сфери управління якого належить підприємство. Тому участь іноземців у складі наглядової ради зумовлює значні витрати, бо розмір винагороди, що підлягає виплаті $\epsilon$ дещо завищеним, не враховує неповну занятість членів наглядової ради та той факт, що член наглядової ради може одночасно бути членом наглядових рад кількох юридичних осіб, відповідно до Постанови Кабінету Міністрів України від 10 березня 2017 р. № 142.

\section{Література:}

1. Мягкий А. В. Корпоративне управління за законодавством України: дис. ... канд. юрид. наук: 12.00.04. Науково-дослідний інститут приватного права і підприємництва імені академіка Ф. Г. Бурчака Національної академії правових наук України. К., 2017. - С. 178. 